\title{
7062 SAYILI YÜKSEK SEÇIMM KURULU'NUN TEŞKİLAT VE GÖREVLERİ HAKKINDA KANUN ÜZERİNE DEĞERLENDİRMELER
}

\author{
REVIEW ON THE LAW NO. 7062 ON ORGANIZATION AND DUTIES \\ OF THE SUPREME ELECTION COUNCIL
}

DOI: $10.21492 /$ inuhfd.429242

\section{Deniz POLAT AKGÜN*}

\section{Özet}

Seçimler, demokrasinin vazgeçilmez unsurudur. Yalnızca seçimlerin varlığ demokrasi için yeterli olmasa da; seçim olmadan demokratik bir yönetimden bahsetmek de mümkün değildir. Bununla birlikte, bir rejimin demokratik sayılabilmesi için seçimlerin de bir takım nitelikleri taşıması gerekir. Buna göre; seçimler, serbest, adil ve güvenilir olmalıdır. Gerçekten de, yalnızca belirli zaman aralıklarıyla oy sandığına gidiliyor oluşu, o yönetimin demokratik olarak nitelendirilebilmesi için tek ölçüt değildir. Serbest, adil ve güvenilir seçimlerden söz edebilmek için de öncelikle seçim mevzuatında, seçimleri serbest, adil ve güvenilir kılacak kurumlara ve mekanizmalara yer verilmesi yaşamsaldır. Dolayısıyla, seçim takviminin başlangıcından bitişine kadar her türlü seçim uyuşmazlığında son yetkili merci olan Yüksek Seçim Kurulu'nun teşkilatına, işleyişine ve çalışma düzenine ilişkin yapılacak bir düzenleme büyük önem taşımaktadır. Çalışmada, öncelikle, 7062 sayılı Yüksek Seçim Kurulu'nun Teşkilat ve Görevleri Hakkında Kanun bu ölçütler çerçevesinde değerlendirilecektir. Ardından, düzenlemenin, seçim hukukundaki ihtiyaçlara cevap verip veremediği, seçim hukukuna ilişkin mevzuat ve Yüksek Seçim Kurulu kararları çerçevesinde ele alınacaktır.

Anahtar Kelimeler: Anayasa, seçim hukuku, seçim uyuşmazlıkları, Yüksek Seçim Kurulu, 7062 sayılı Yüksek Seçim Kurulu'nun Teşkilat ve Görevleri Hakkında Kanun.

\footnotetext{
Abstract

Elections are indispensable elements for democracy. Although the existence of elections is not sufficient for democracy, it is impossible to consider a government as "democratic" without elections. However, in order for a regime to be considered democratic, elections must have a number of qualities. Accordingly, elections should be free, fair and reliable. Indeed, going to the polls periodically is not the only criterion for a government to qualify as democratic. In order to speak of free, fair and reliable elections, it is vital that the institutions and mechanisms that will make the elections free, fair and reliable are included in the electoral legislation. Since the Supreme Election Council is the supreme authority on electoral disputes from the beginning of the electoral calendar, a legislation regarding the organization, functioning and working order of it is of great

* Araştırma Görevlisi, Ankara Üniversitesi, Hukuk Fakültesi, Anayasa Hukuku Anabilim Dal1. (E-mail: deniz06286@gmail.com)

Makale Gönderilme Tarihi: 31.05.2018

Makale Kabul Tarihi: 20.06.2018
} 
importance. First of all, this article deals with the Law No. 7062 on Organization and Duties of the Supreme Election Council within the framework of these criteria. Secondly, within the scope of the legislation on electoral law and the decisions of the Supreme Election Council, it will be argued whether or not the new regulation meets the requirements of the electoral law.

Keywords: Constitution, electoral law, electoral disputes, the Supreme Election Council, the Law No. 7062 on Organization and Duties of the Supreme Election Council.

\section{GíRiş}

Demokrasi kavramını nasıl anladığımız, demokratik kurumların tasarlanmasına ve iyileştirilmesine yönelik tercihlerimize de rehberlik eder $^{1}$. Bu kurumların başında seçimler gelir. Demokratik bir devlette, siyasi tercihler ve siyasi iktidar seçimler yoluyla belirlenir; gerektiğinde de yine seçimler yoluyla el değiştirir ${ }^{2}$. Elbette ki, seçim mekanizması, demokrasi için tek başına yeterli bir ölçüt değildir. Ne var ki, demokrasinin vazgeçilmez unsuru niteliğindeki seçimler olmadan demokratik bir yönetimden bahsetmek de mümkün değildir. Bir yönetimin demokratik olarak tanımlanabilmesi içinse, seçimlerin de bir takım özelliklere sahip olması gerekir. Bu çerçevede, seçimlerin serbest, adil ve güvenilir olması büyük önem taşır.

Serbest, adil ve güvenilir seçimlerden söz edebilmek için öncelikle seçim mevzuatında, seçimleri serbest ve adil kılacak kurum ve kurallara ve bunların etkin bir biçimde uygulanmasını sağlayacak mekanizmalara yer verilmesi; dolayısıyla, uygun hukuki altyapının kurulması gerekir ${ }^{3}$. Bu açıdan, seçim uyuşmazlıklarının çözümüne ilişkin en üst merci olan Yüksek Seçim Kurulu'nun teşkilatına, görevlerine, işleyişine ve çalışma düzenine ilişkin hukuki düzenlemeler özellikle önemlidir. Çalışmanın konusunu oluşturan 7062 sayılı Kanun, bu nedenle ayrı bir incelemeyi gerekli kılmaktadır.

Yüksek Seçim Kurulu'nun (YSK) yapısına ve işleyişine ilişkin düzenlemeler içeren 7062 sayılı "Yüksek Seçim Kurulu'nun Teşkilat ve Görevleri Hakkında Kanun" 30 Kasım 2017 tarihinde Türkiye Büyük Millet Meclisi'nde kabul edilmiştir. Cumhurbaşkanı tarafından onaylanan

${ }^{1}$ OWEN, David: "Democracy", Political Concepts içinde, Bellamy, Richard / Mason, Andrew (ed.), Manchester University Press, Manchester 2003, s. 105.

2 OWEN, s. 105-107; PRZEWORSKI, Adam: "Minimalist Conception of Democracy: A Defense", Democracy's Value içinde, SHAPIRO, Ian / HACKER-CORDON, Casiano (ed.), Cambridge University Press, Cambridge 1999, s. 46-47.

${ }^{3}$ GÖNENÇ, Levent: Türkiye'de Seçim Uyuşmazlıkları ve Çözüm Yolları (2008), Adalet Yayınevi, Ankara 2008, s. 2. 
Kanun, 12 Aralık 2017 tarihinde Resmi Gazete'de yayımlanarak yürürlüğe girmiştir ${ }^{4}$.

Kanunun gerekçesinde, son yıllarda yapılan Anayasa değişiklikleri ile artan seçimler; nüfus artışına bağlı olarak artan seçmen sayısı ve bunlara bağlı olarak değişen ihtiyaçlar karşısında YSK'nın artan iş yüküne değinilmiş ve bu nedenlerle ayrı bir teşkilat kanununun düzenlenmesine ihtiyaç duyulduğu ifade edilmiştir. Ayrıca, YSK'nın ve birimlerinin görevleri, personelin atanması usulü ve özlük işleri gibi aslen bir teşkilat kanununda düzenlenmesi gereken konulara 298 sayılı Kanun'da dağınık şekilde yer verildiği; bu kuralları bir araya getirmek ve Kurul'un teşkilat yapısını güçlendirmek adına ayrı bir kanuna gerek görüldüğü belirtilmiștir.

I. YÜKSEK SEÇIM KURULU'NUN OLUŞUMUNA VE KARAR VERME USULÜNE İLIŞKINN DÜZENLEMELER

Öncelikle, 7062 sayılı Kanun'un gerekçesinde de yer alan YSK'ya ilişkin kuralların seçim mevzuatı içinde dağınık bir görünüm çizdiği tespitine katılmak gerekir'. Söz konusu hükümler, Anayasa'nın 79. maddesinde, 298 sayılı Seçimlerin Temel Hükümleri ve Seçmen Kütükleri Hakkında Kanun'da ve 2820 sayılı Siyasi Partiler Kanunu ile 2839 sayılı Milletvekili Seçimi Kanunu'nda yer almaktadır. Bu durum, YSK'nın işleyişine ve seçim uyuşmazlıklarına ilişkin birçok konuda yeknesak olmayan düzenlemelere ve dolayısıyla tartışmalara neden olmaktadır. Bununla birlikte, 7062 sayılı Kanun ile bu dağınık görünümün ve bunun yarattığı sorunların giderilip giderilmediği ise kuşkuludur.

7062 sayılı Kanun'un getirdiklerini incelemeye geçerken ilk olarak değinilmesi gereken, YSK'nın oluşumu ve görevleri başlığıdır. Anayasa'nın 79. maddesine göre YSK, yedi asıl ve dört yedek üyeden oluşur. Üyelerin altısı Yargıtay, beşi Danıştay Genel Kurullarınca kendi üyeleri arasından üye tamsayılarının salt çoğunluğunun gizli oyu ile seçilir. Yedek üyeler ise seçim aşamasında değil, seçildikten sonra ad çekme usulüyle belirlenir. 7062 sayılı Kanun'un, Kurul'un oluşumunu düzenleyen 4. maddesi, Anayasa'nın bu hükmünü tekrar etmiştir. Burada dikkate alınması gereken husus ise YSK üyelerinin kendi kurumlarıyla olan ilişkilerinde ortaya çıkan özlük hakları tartışmasıdır.

\footnotetext{
${ }^{4}$ Bkz. RG. 12.12.2017, S. 30268.

${ }^{5}$ Kanunun gerekçesi için bkz. TBMM Başkanlığı, Esas No. 2/1929, 21 Kasım 2017, s. 13 14.
} 
Yargıtay ve Danıştay üyeleri arasından seçilmeleri dolayısıyla YSK üyeleri "yüksek yargıç" statüsündedir. Bu konuda bir kararsızlığa yer olmamakla birlikte; YSK üyelerinin, üyelikleri süresince idari ve mali açıdan bağlı oldukları yüksek yargı kurumlarıyla olan ilişkileri geçmişte tartışma konusu olmuştur. Bunun nedeni, mevzuatta konuya ilişkin açık bir düzenleme olmamasıdır. Bugüne kadar 298 sayılı Kanun'un, YSK Başkanı'nın özlük haklarını düzenleyen 11. maddesi dikkate alınmış ve söz konusu hükmün kıyasen diğer üyelere de uygulanıp uygulanamayacağı tartışılmıştır. Maddenin 7. fikrasına göre; Kurul'un Başkanı, başkanlık görevi süresince, kurumundan izinli sayılır. Ancak, kurumundaki aylık, ödenek ve her türlü zam ve tazminatlar ile diğer özlük haklarından aynen yararlanmaya devam eder ${ }^{6}$. Bununla birlikte, öğretide, argumentum a contrario ilkesi gereği bu tür bir ayrıcalığın yalnızca Kurul'un Başkanı'na tanındığı; dolayısıyla, YSK Başkanvekili ve diğer üyelerin bu haklara sahip olmadığı ifade edilmektedir? 7062 sayılı Kanun ise konuya ilişkin açık bir düzenleme getirerek, tartışmalara son vermiş görünmektedir ${ }^{8}$. Kanun'un 4/10 maddesine göre Başkan ve Başkanvekili, görevleri süresince; üyeler ise ihtiyaç duyulması hâlinde, Kurulca belirlenen süre zarfinda kurumlarından izinli sayılırlar. Ancak, kurumlarındaki aylık, ödenek ve her türlü zam ve tazminatlar ile diğer özlük haklarından aynen yararlanmaya devam ederler.

Yüksek Seçim Kurulu'nun oluşumuna ilişkin bir diğer tartışmalı konu yedek üyelerin statüsü, görev ve yetkilerine ilişkindir. Hemen belirtmek gerekir ki, asıl üyeliklerden birinin herhangi bir sebeple sona ermesi halinde, bu üyeliklerin yedek üyeler tarafindan $\mathrm{m}$ doldurulacağ 1 veya böyle bir sona erme durumunda seçimlerin ne zaman yapılacağı; asıl üyeler mazeretli olduklarında yedek üyelerin toplantılara katılıp katılamayacakları yahut asıl üyeyi ikame edecek olan yedek üyenin, asıl üyenin seçildiği kurum dikkate alınarak $\mathrm{m} 1$ üyeliğe vekalet edeceği gibi sorular tartışma yaratabileceği gibi; bu olası sorunlara ilişkin 298 sayılı Kanun'da da bir açıklı yoktur'. Söz konusu sorulara yorum yoluyla ve YSK'nın kararları çerçevesinde çözümler aranmıştır. Ne var ki, 7062 sayılı Kanun da bu sorunların tamamına çözüm sunamamaktadır.

\footnotetext{
${ }^{6}$ Söz konusu fikra, 298 sayılı Kanun'un 11. maddesine 05.06.1997 tarihli ve 4265 sayılı Seçimlerin Temel Hükümleri ve Seçmen Kütükleri Hakkında Kanunda Değişiklik Yapılmasına İlişkin Kanun ile eklenmiştir.

${ }^{7}$ GÖNENÇ, 2008, s. 114.

87062 sayılı Kanun'un 12/6 maddesi ile 298 sayılı Kanun'un 11. maddesi de yürürlükten kaldırılmıştır.

${ }^{9}$ Ayrıntılı bilgi için bkz. GÖNENÇ, 2008, s. 115.
} 
Yalnızca, Kanun'un 4/8 maddesi “Kurul üyelerinin görev süresi dolmadan herhangi bir sebeple üyeliklerinin sona ermesi hâlinde, bu üyelerin yerine yeni üye seçimi yapılır" diyerek, asıl üyeliklerin herhangi bir sebeple sona ermesi halinde, bu üyeliklerin yedek üyeler tarafindan $\mathrm{m}$ doldurulacağı yoksa yeni üye seçimi mi yapılacağı sorusuna açık cevap verir niteliktedir. Ancak, hemen belirtmek gerekir ki, söz konusu kural, 298 sayılı Kanun'da yer almamakla birlikte, YSK'nın kararı ile geçmişte de çözüme kavuşturulmuştur. YSK'nın konuyla ilgili kararına göre; YSK'da, Kurul'un dönemi içinde herhangi bir üyelik açıldığ zaman, Yargıtay ve Danıştay Genel Kurullarınca boş üyeliği doldurmak üzere yapılacak seçim sonucunda seçilecek üyenin, yerini doldurduğu üye gibi; as1l veya yedek üye olarak Kurul'da bulunması gerekmektedir ${ }^{10}$. Kararda, boş üyeliği doldurmak üzere yapılacak seçim denildiğine göre, herhangi bir sebeple sona eren üyelik, yedek üye tarafından değil; yeni seçilen üye tarafından doldurulacaktır. 7062 sayılı Kanun ise söz konusu kararı ve devam eden uygulamay1 kanun hükmüne dönüştürmüştür. Bununla birlikte, bir noktayı da gözden kaçırmamak gerekir. YSK'da bir üyeliğin herhangi bir sebeple sona ermesini takiben yapılacak yeni üye seçimi için ne 7062 sayılı ne de 298 sayılı Kanun'da bir zaman sinırı vardır. Dolayısıyla, söz konusu yeni üye seçiminin ne zaman yapılacağına dair bir açıklık olmadığını söylemek mümkündür. Bu konuda, Kurul'un sürekliliği ilkesi yol gösterici olabilirr ${ }^{11}$. Öyle ki, bu ilke gereği, boşalan üyelikler için seçimin en kısa zamanda yapılması ve seçime kadar geçecek süre zarfinda da boşalan üye yerine yedek üyenin toplantılara katılması gerektiği kabul edilmelidir ${ }^{12}$. Buna karşın, yedek üyelikle ilgili diğer sorunların 7062 sayılı Kanun'da ele alınmadığı görülmektedir. Öyleyse, olas1 sorunların, daha önceden izlenen yöntemler ve yorumlar çerçevesinde çözümlenmeye çalışılacağını ifade etmek mümkündür ${ }^{13}$.

\footnotetext{
${ }^{10}$ Bkz. YSK, 1963/25, RG. 21.09.1963, S. 11511.

11 Yüksek Seçim Kurulu'nun sürekliliğine ilișkin YSK Kararı için bkz. YSK, 1962/405, RG. 01.03.1962, S. 11048.

${ }^{12}$ Aynı yönde bkz. GÖNENÇ, 2008, s. 116.

13 Örneğin, asıl üyeyi ikame edecek olan yedek üyelerin seçildikleri kurum dikkate alınarak mı üyeliğe vekâlet edecekleri sorusu da öğretide cevap bulmaktadır. Buna göre, YSK üyeleri arasında geldikleri yüksek yargı yerlerinin farklı olmaları dışında, herhangi bir statü, seviye veya işlev farkı yoktur. Dolayısıyla, Yargıtay Genel Kurulunca seçilmiş bir asıl üyeyi Danıştay Genel Kurulunca seçilmiş bir yedek üyenin ikame etmesinde herhangi bir sorun yoktur. Aynı saptama, mazeretli olduklarında toplantıya katılamayan asıl üyelere vekâlet eden yedek üyeler için de geçerli olmalıdır. Söz konusu yorumlar ve sorunlara çözüm önerileri hakkında ayrıntılı bilgi için bkz. GÖNENÇ, 2008, s. 115-116.
} 
7062 sayılı Kanun'a ilişkin tartışılması gereken bir diğer başlık, Kurul'un karar yetersayısına ilişkin hükümdür. Kanun'un 5. maddesine göre YSK, kararlarını salt çoğunlukla alır. Oyların eşitliği hâlinde Başkanın bulunduğu tarafın görüşü doğrultusunda karar verilmiş olur. Görüldüğü üzere, ilgili hükümle, yalnızca karar yetersayısı düzenlenmiş;; şimdiye kadar asıl tartışma konusu olan toplantı yetersayısına ilişkin ise herhangi bir düzenlemeye yer verilmemiştir. Oysa ki, seçim uyuşmazlıklarının çözümünde, uyuşmazlık çözme makamlarının toplantı ve karar yeter sayıları açısından hangi yöntemleri kullanacağı özellikle önemlidir. Öyle ki, yeter sayılara ilişkin saptanan kurallar, karar alma sürecini de doğrudan etkilemektedir. Buna karşın, mevzuattaki dağınık hükümleri sistematik biçimde düzenlemek iddiasında olan 7062 sayılı Kanun'un, özellikle toplantı yetersayısına ilişkin bir açıklık getirmemiş olması eleştiriye açıktır.

YSK'nın toplant1 yeter sayıs1 298 sayıl1 Kanun'un itiraz yoluna ilişkin 113. maddesinde düzenlenmektedir. Hükme göre, "Yüksek Seçim Kurulu, seçimin sonunda verilecek tutanaklara karşı yapılan itirazların incelenmesinde, tam saylsı ile toplanır. Diğer hususlarda kurulun mürettep adedinin çoğunluğu ile toplanabilir." Tartışmaya geçmeden önce madde metnindeki "tam sayı" ve mürettep adet" kavramlarına açıklık getirmek gerekir. Mürettep adet, herhangi bir meclisi veya heyeti oluşturan oy sahibi üyelerin, hazır olsun veya olmasın, hepsinin oluşturduğu sayıdır ${ }^{14}$. Başka bir ifadeyle, "üye tam sayısı" anlamına gelmektedir. Buradaki sorun ise, 113. maddenin hem "tamsayı" hem de "mürettep adet" terimlerini, sanki farklı anlamlara geldikleri izlenimini yaratacak biçimde, aynı maddede kullanmış olmasıdır. Maddenin gerekçesinde, sahip olduğu önem nedeniyle, seçim sonunda düzenlenen tutanaklara karşı yapılan itirazların incelenmesinde YSK'nın tam sayı ile toplanarak; salt çoğunlukla karar vermesi konusunda 5545 sayılı Kanun'da yer alan hükmün aynen korunduğu ifade edilmektedir ${ }^{15}$. Dolayısıyla, 16.02.1950 tarihli ve 5545 sayılı Milletvekilleri Seçimi Kanunu'ndaki ${ }^{16}$ hükümlerin, 298 sayılı Kanun'u yorumlarken dikkate

14 Bkz. TÜRK HUKUK KURUMU: Türk Hukuk Lûgatı, Başbakanlık Mevzuatı Geliştirme ve Yayın Genel Müdürlüğü, 3. b., Ankara 1991, s. 257.

15 Bkz. HATİPOĞLU, Muzaffer / PARLAR, Ali: Açıklamal1-Gerekçeli-İçtihatlı Seçim Kanunları ve Seçim Suçları, Ankara 2004, s. 261.

${ }^{16} 5545$ sayılı Kanun'un ilk hali için bkz. RG. 21.02.1950, S. 7438. Kanun'un 6272 sayılı Kanun ile değiştirilmiş hali için bkz. RG. 23.02.1954, S. 8641. Ayrıca bkz. ERDEM, Tarhan: Anayasalar ve Seçim Kanunları: 1876-1982, Milliyet Yayınları, İstanbul 1982, s. $227 ; 239-240$. 
alınmas1 gerekecektir. 5545 sayılı Kanun'un ilgili 122. maddesinin 1. fikrasına göre, "Yüksek Seçim Kurulu'nun, bu Kanun'un 123. maddesinin 3, 4 ve 5. bentlerindeki itirazları tetkik ederek karara bağlayabilmesi için adedi mürettebi olan 11 kişi ile toplanması şarttır ${ }^{17}$." Maddenin 2. fikrasına göre de "Diğer hususlarda Kurul, adedi mürettebinin ekseriyetiyle de toplanabilir ve her iki halde de mutlak ekseriyetle karar verir." O halde, mürettep adet açıkça 11 kişi olarak belirlenmiştir. Söz konusu hüküm, 5545 sayılı Kanun'un YSK'nın oluşumunu düzenleyen 120. maddesiyle birlikte ele alınmalıdır. 120. maddenin 1. fikrasına göre ise, "Yüksek Seçim Kurulu bir başkan ve on üyeden teşekkül eder." $\mathrm{O}$ halde, Kanun'daki "mürettep adet" ifadesiyle yalnızca "asıl üyelerin toplamı"nın kastedildiği anlaşılmaktadır ${ }^{18}$.

298 sayılı Kanun'un, YSK'nın toplantı yetersayısına ilişkin 113. maddesindeki düzenlemeye baktığımızda ise iki farklı toplantı türünün belirlendiği görülür. Toplantı yetersayısına ilişkin kurallar da buna göre farklılık arz etmektedir. Maddenin 3. fikrasına göre, tutanaklara karşı yapılan itirazların incelenmesinde toplantı yetersayısı üye tam sayıs1; yani asıl üyelerin toplamıdır. Başka bir ifadeyle, YSK, tutanak itirazlarını 7 üyenin katılımıyla inceler. 113. maddenin 4. fikrasına göre ise Kurul, diğer hususlarda mürettep adedinin çoğunluğu ile toplanabilir. Yani, tutanak itirazı dışındaki diğer tüm konularda YSK'nın toplantı yetersayısı, mürettep adedinin (üye tamsayısının) çoğunluğu olan 4'tür ${ }^{19}$.

17 Söz konusu itirazlar, 5545 sayılı Kanun'un 123. maddesinde kaleme alınmıştır. Maddenin 3. bendine göre, "îl seçim kurullarının teşekkülüne, işlemlerine ve kararlarına karşı yapılmış olup da, zamanında kesin karara bağlanmamış olan itirazlar”; 4. bendine göre, "milletvekilliğine seçildiğine dair tutanak verilen bir kimsenin seçilmemesini mucip olacak vakıalar hakkındaki itirazlar" ve 5. bendine göre, "milletvekilliğine seçildiğine dair tutanak verilen bir kimsenin seçilme yeterliliğini hazi olmadığına dair yapılan itirazlar" bu kapsamdadır. Bkz. Erdem, 239-240.

${ }^{18}$ DEMİROĞLU, Kemal / KARAGIL, Nevzat: Yeni Seçim Kanunlarının Mufassal Şerhi ve Tatbikat1, Sıralar Matbaası, İstanbul 1961, s. 27; GÖNENÇ, 2008, s. 85.

${ }^{19}$ GÖNENÇ, 2008, s. 86; COŞKUN, Sabri: Seçim Hukuku, Mahalli İdareler Derneği Yayınları, Ankara 2007, s. 462; DEMİROĞLU / KARAGİL, s. 27. YSK da bir kararında; "298 sayılı Kanun'un 113. maddesinde gereğince, yalnız YSK'nın çoğunlukla toplanabileceği hükme bağlanmış olup; diğer kurullar için böyle bir kural gerek bu maddede gerekse diğer maddelerde kabul edilmiş değildir" diyerek; Kanun'da belirtilen hallerde çoğunlukla toplanabileceğini ifade etmiştir. Bkz. YSK 21.09.1963/37, RG 27.09.1963, S. 11516. Her ne kadar, 298 sayılı Kanun'da YSK'nın toplantı yetersayısı bu şekilde belirlenmiş olsa da; uygulamada Kurul toplantılarının asıl ve yedek tüm üyelerin katılımıyla gerçekleştiği not edilmelidir. Toplantıya katılan yedek üyeler, oy kullanmasalar da konular üzerinde görüş bildirebilmektedirler. Bunun yanında, eğer 
Öncelikle, 7062 sayılı Kanun, toplantı yetersayısına ilişkin herhangi bir düzenlemeye yer vermediğinden; Kurul'un toplantı ve karar yetersayıları farklı kanunlarda hükme bağlanmış olmaktadır. İkinci olarak, kanun koyucunun seçim sürecinde ortaya çıkacak uyuşmazlıklar ve toplantı türleri arasında neden böyle bir ayrıma gittiğini anlamak da güçtür. Bu açıdan, 298 sayılı Kanun'un 113. maddesinin gerekçesinde söz edildiği gibi, diğer seçim uyuşmazlıklarının, tutanaklara karşı yapılan itirazlardan daha az önemli olduğunu kabul etmek de mümkün değildir ${ }^{20}$. Bunun yanında, maddedeki bir diğer sorun terim karmaşasıdır. Aynı anlama gelen "üye tam sayısı" ve "mürettep adet" ifadelerinin kullanım tercihleri nedeniyle yaratılan karışıklık henüz giderilebilmiş değildir. Yine, "adedi mürettep" ifadesinden yalnızca asıl üyelerin mi anlaşılacağı, geçmiş Kanun hükümlerine bakılarak, yorum yoluyla cevaplanmaya çalışılacaktır. Ayrıca, söz konusu terminolojik karmaşa, evrensel seçim hukuku ölçütlerine de uygun değildir. Öyle ki, uluslararası seçim hukuku kaynaklarında, seçimlere ilişkin her türlü hukuki düzenlemede kullanılan dilin tutarlı, anlaşılır ve açık olması gerektiği; ayrıca dilde yeknesaklığın önemi siklıkla ifade edilmektedir ${ }^{21}$.

7062 sayılı Kanun, Yüksek Seçim Kurulu'nun karar yetersayısını ise 298 sayılı Kanun'a paralel şekilde düzenlemiştir. 298 sayılı Kanun'un 13. maddesine göre; Kurul, kararlarını salt çoğunlukla verir; oyların eşitliği halinde başkanın katıldığı taraf üstün tutulur. Görüldüğü üzere, 7062 sayılı Kanun ile 298 sayılı Kanun'un ilgili hükümleri arasında herhangi bir fark yoktur. Burada değinilmesi gereken husus, başkanın katıldığı tarafın üstün tutulması yönteminin devam ettirilmiş olmasıdır. Öğretide de ifade edildiği üzere, seçim sürecinin kendine özgü nitelikleri düşünüldüğünde, seçim uyuşmazlıklarında, bu sürece katılanların tümü veya büyük bir çoğunluğu tarafindan kabul edilebilecek bir kararın alınmasına elverişli bir yöntem benimsenmelidir ${ }^{22}$. Başkanın görüşünün

gündemdeki konu, yedek üyenin uzmanlık alanına giriyorsa, bu durumda konuyu Kurul'a yedek üye sunar ve oy hakkını da kullanır. Ayrıntılı bilgi için bkz. COŞKUN, s. 102.

${ }^{20}$ GÖNENÇ, 2008, s. 86. Yazara göre, eğer seçim uyuşmazlıkları arasında bir ayrım yapılacaksa, idari işlevlere ilişkin uyuşmazlıklar ile kazai işlevlere ilişkin uyuşmazlıklar arasında bir ayrıma gidilmesi düşünülebilir.

${ }^{21}$ OFFICE FOR DEMOCRATIC INSTITUTIONS AND HUMAN RIGHTS (OSCE): "Resolving Election Disputes in the OSCE Area: Towards a Standard Election Dispute Monitoring System", 2000, para. 18, s. 11, https://www.osce.org/odihr/elections/17567?download=true, (Erişim Tarihi: 20.03.2018).

${ }^{22}$ GÖNENÇ, 2008, s. 83. 
üstün tutulması usulü ise bu uzlaşmayı sağlayabilecek en elverişli yöntem değildir. Örneğin, YSK, tutanaklara itirazlar dışındaki diğer konulara ilişkin gerçekleştirilen bir toplantıda, üyelerinin çoğunluğu ile yani dört kişi ile toplanabilecektir. Bu durumda, iki üye aynı yönde oy kullanıp, diğer iki üye de aksi yönde oy kullanacak olursa; YSK Başkanı'nın oy vermek istediği taraf üstün tutulacaktır. $\mathrm{Bu}$ ise, zaten az bir çoğunlukla alınabilecek olan bir kararın, daha az uzlaşmacı ve daha az demokratik bir yöntemle alınmasına yol açacaktır. Dolayısıyla, en azından üç üyenin oy çoğunluğunun gerekli olduğu şeklinde bir düzenlemeye gidilmesinin daha uygun olacağı yönündeki görüşlere katılmak mümkündür ${ }^{23}$.

Kurul'un karar verme sürecine yönelik değinilmesi gereken son değişiklik, kararların yayımlanmasına ilişkindir. 7062 sayılı Kanun'un 5/2 maddesine göre, "Kurulun prensip kararları on beş gün içerisinde Resmî Gazete'de yayımlanır; seçime ilişkin diğer kararları ise Kurulun resmî internet sitesinde yayımlanır." Kanun, 298 sayılı Kanun'un aynı konuyu düzenleyen 13. maddesini de ilga etmiştir. Söz konusu 13. madde, Yüksek Seçim Kurulu'nun nihai kararları ile prensip kararlarının Resmi Gazete'de en kısa zamanda yayımlanmasını öngörmekteydi. Dolayısıyla, kararların yayımlanma süresine ilişkin herhangi bir açık süre sınırı yoktu. Düzenlemede her ne kadar "en kısa zamanda" ifadesi geçse de, uygulamada Kurul'un kararlarının yayımlanması zaman alabilmekteydi. 7062 sayılı Kanun ise kararların yayımlanmasına belirli bir süre sınırı getirmiş ve Kurul'un bu konudaki takdir yetkisini sınırlamıştır. Demokratik seçim ilkesi gereğince, kararların en kısa sürede açıklanması ve herkesçe ulaşılabilmesi önemlidir. $\mathrm{Bu}$ açıdan, düzenlemeyle süre sınırına gidilmesi olumlu bir gelişme olarak değerlendirilebilir. Ne var ki, on beş gün olarak belirlenen söz konusu süre sınırı, yalnızca Kurul'un ilke kararları için geçerli kılınmıştır. Seçime ilişkin diğer kararların yayımlanması için herhangi bir süre öngörülmediği gibi; bu kararların Resmi Gazete'de yayımlanma zorunluluğu da yoktur. Öyle ki, Kanun, "resmî internet sitesinde yayımlanır" ifadesiyle, seçime ilişkin kararların yalnızca Kurul'un resmi internet sitesinde yayımlanacağını belirterek; bunun dişında Resmi Gazete'de yayımlanmayacağını kaleme almış olmaktadır. Başka bir ifadeyle, Kanun, Kurul'un resmi internet sitesini resmi yayın organı olarak kabul etmiş ve seçime ilişkin kararların yalnızca burada yayımlanmasını zorunlu ve yeterli görmüştür. Usûl ekonomisi ve kararlara erişim kolaylığı açısından bu kabul elverişli görülebilir. Bununla

\footnotetext{
${ }^{23}$ Bkz. DEMİROĞLU / KARAGIIL, s. 27.
} 
birlikte, seçime ilişkin kararlar büyük tartışmalara, hatta kimi zaman seçim sürecinde ve sonucunda değişikliklere yol açabilmektedir. Bu açıdan, ilke kararları yanında, seçime ilişkin diğer kararların da yayımlanması için belirli bir süre sınırının öngörülmesinin daha yerinde olacağı düşünülebilir.

\section{YÜKSEK SEÇIM KURULU'NUN TEŞKILATINA ILISSKIIN DÜZENLEMELER}

7062 sayılı Kanun ile Yüksek Seçim Kurulu'nun teşkilat yapısında da bir takım değişikliklere gidilmiştir. Kanun'un 7. maddesine göre, Kurul, merkez ve taşra teşkilatı olmak üzere iki ana birimden oluşacaktır ${ }^{24}$. Madde kapsamında Kurul'un idari fonksiyonlarını üstlenecek yeni birimler kurulmuştur. Düzenleme bu açıdan olumlu sayılmalıdır. Öyle ki, YSK'nın kazai (yargısal) ve idari (yönetsel) işlevlerinin ayrılarak; idari işlevlerine dahil olan görevlerinin, yeni oluşturulacak bir seçim bürokrasisine verilmesi gerektiği; böylece Kurul'un yargısal işlevlerini daha verimli şekilde yerine getirebileceği önerisi, öğretide de dile getirilmiştir ${ }^{25}$.

Kanun'un söz konusu 7. maddesine göre ilçe ve yurt dişı ilçe seçim kurullarına bağlı seçim müdürlükleri oluşturulmaktadır. Burada dikkate sunulması gereken nokta, seçim müdürlüklerinde görev yapacak olan seçim müdürleri ve seçim müdür yardımcılarının göreve alınma usulleridir.

Kanun'un 10/3 maddesine göre,

"seçim müdürü ve seçim müdür yardımcıları, Kurul personeli arasında yapılacak veya yaptırılacak yazılı ve sözlü sınav sonucuna göre Başkan tarafindan atanır".

Kanun'un 10/4 maddesine göre ise

"seçim müdürü ve seçim müdür yardımcllı̆̆ına atanacaklarda, hukuk fakültesi veya siyasal bilgiler, idari bilimler, iktisat ve maliye alanlarında en az dört yıllık yükseköğrenim yapmış veya bunlara denkliği kabul edilmiş yabancı ögretim kurumlarından mezun olma şartı aranır."

${ }^{24} 7062$ sayılı Kanun madde 7: (1) Kurul teşkilatı, merkez ve taşra birimlerinden oluşur.

(2) Merkez teşkilat1; Seçmen Kütüğü Genel Müdürlüğü, Seçim Hizmetleri Genel Müdürlüğü, İnsan Kaynakları Dairesi Başkanlığı, Strateji Geliştirme Dairesi Başkanlığı ve Özel Kalem Müdürlüğünden oluşur.

(3) Taşra teşkilatı; ilçe ve yurt dışı ilçe seçim kurullarına bağlı seçim müdürlüklerinden oluşur. Kurul, gerekli görülen illerde, il seçim kuruluna bağlı seçim müdürlüğü kurabilir.

${ }^{25}$ GÖNENÇ, 2008, s. 30; GÖNENÇ, Levent: "Yüksek Seçim Kurulu Yasası Üzerine Bir Değerlendirme" (2017), Türkiye Ekonomi Politikaları Araştırma Vakfı, Aralık 2017, s. 2. 
Yine, Kanun'un 10/7 maddesine göre;

"seçim müdürü ve seçim müdür yardımcllarl, nüfusa kayıtlı oldukları ilçelerde görev yapamazlar; geçici görevde geçen süreler de dâhil ayn yerde altı yıldan fazla çalışamazlar. Ancak bu süreyi dolduranlar, ihtiyaç duyulması hâlinde Başkanın kararıyla en fazla bir yıl daha ayn yerde çalışabilirler".

7062 sayılı Kanun'un 10. maddesinde, seçim müdürlerinin ve yardımcılarının nasıl seçileceği, seçilmek için gerekli olan şartların neler olduğu ve görev sürelerinin kaleme alınmış olması olumlu olarak değerlendirilebilir. Buna karşın, seçim süresince önemli görevler üstelenecek olan bu personelin sözlü sınav yöntemiyle seçilmesi, yöntemin nesnelliği açısından tartışma yaratabilecek niteliktedir ${ }^{26}$. Eklemek gerekir ki, seçim müdürü ve seçim müdür yardımcılarının atanmasına ilişkin yetkinin Kurul'a değil de doğrudan "Başkan'a" verilmiş olması ve yine görev sürelerini dolduran personelin çalışmaya devam edebilmeleri için Kurul'un değil, "Başkan'ın” kararına ihtiyaç duyulması da eleştiriye açıktır. Kurul'un teşkilat yapısı içinde yer alan seçim müdürlüğü ve seçim müdür yardımcılığı gibi üst düzey kadrolarda görev alacak personelin belirlenmesinde büyük çapta bir uzlaşmanın aranması, şeffaf bir seçim ve tarafsızlık tartışmalarının giderilebilmesi adına önemlidir. Söz konusu atamaların tek bir kişinin yetkisine bağl1 olması ise bu tartışmaları gündeme getirebilecek niteliktedir.

7062 sayılı Kanun ile yapılan değişikliklere ilişkin değinilmesi gereken son başlık, personel alımına ilişkin tercih edilen sınav yöntemleridir. Kanun'da, söz konusu sinavlara yönelik düzenlemelerin yeknesak olmadığı görülmektedir. Örneğin, Kanun'un 10/3 maddesinde, "yazılı ve sözlü sınav" ibaresi yer alırken; 10/5 maddesinde "uygulamalı sınav" ifadesine rastlanmaktadır ${ }^{27}$. Kanun'un başka hiçbir yerinde uygulamalı sınav ibaresine yer verilmemiştir. Dolayısıyla, söz konusu sınav yöntemi ile yazılı sınav arasında bir fark olup olmadığı yahut "yazılı", "sözlü” ve "uygulamalı" sınav olmak üzere üç tür göreve alım usulünün mü belirlendiği Kanun metninden anlaşllamamaktadır. Bu nedenle, konuyla ilgili olarak, Yüksek Seçim Kurulu'nun, 7062 sayılı

\footnotetext{
${ }^{26}$ Aynı yönde bkz. GÖNENÇ, 2017, s. 2.

277062 sayılı Kanun madde 10/5: (5) Kurul kadrolarına ilk defa atanacak diğer personel Kamu Personel Seçme Sınavında, yönetmelikte belirlenen puan türünde asgari puanı almış olanlar arasından, yapılacak sözlü ve gerektiğinde uygulamalı sınav sonucuna göre Başkan tarafından atanır. Sınava, ilan edilecek kadro sayısının beş katına kadar aday çağrılır.
} 
Kanun sonrasında çıkarmış olduğu ve 18 Şubat 2018 tarihli Resmi Gazete'de yayımlanan, "Yüksek Seçim Kurulu Memur Sınav, Atama, Yer Değiştirme ve Nakil Yönetmeliği" ile "Yüksek Seçim Kurulu Personeli Görevde Yükselme ve Unvan Değişikliği Yönetmeliği"ne bakmak yerinde olacaktır ${ }^{28}$. Adı geçen yönetmeliklerden, "Yüksek Seçim Kurulu Memur Sınav, Atama, Yer Değiştirme ve Nakil Yönetmeliği", sözlü sınava ek olarak uygulamalı sınav yöntemine de yer vermiştir. Yönetmelik'in 4/1 maddesinin (i) bendine göre; uygulamalı sınav, ilgilinin atanacağ kadronun gerektirdiği mesleki becerinin değerlendirildiği sınav olarak tanımlanmaktadır. Söz konusu tanımın, yazılı sınav ile uygulamalı sinav arasındaki farkı ortaya koyabilen bir açıklıkta olduğunu söylemek güçtür. Öyle ki, aynı Yönetmelik'in 13. maddesine göre de uygulamalı sınava ilişkin usul ve esaslar ilan edilen sinav duyurusunda belirtilecektir. Bununla birlikte, "Yüksek Seçim Kurulu Personeli Görevde Yükselme ve Unvan Değiş̧ikliği Yönetmeliği"nde ise "uygulamalı sınav" ibaresine hiç yer verilmemiştir. Dolayısıyla, ilk kez atanabilmek veya görevde yer değiştirebilmek için uygulamalı sınav yöntemi kullanılacak; görevde yükselme veya unvan değişikliği söz konusu olduğunda yazılı sınav uygulanacaktır. $\mathrm{Bu}$ tercih farkının gerekçesini saptayabilmek güçtür. Uygulamalı sınav kavramının taşıdığı bu gibi belirsizliklerin ise hem uluslararası seçim hukuku ölçütlerinde yer verilen ve yukarıda da bahsedilen, seçim mevzuatında kullanılan dilin açık ve yeknesak olması gerektiğine yönelik ilkeyi karşılamadığını hem de personel alımını ve dolayısıyla seçim sürecini tartışmalı hale getirebileceğini ifade etmek mümkündür.

${ }^{28}$ Bkz. RG. 18.02.2018, S. 30336. 


\section{SONUÇ}

Seçim takviminin başlangıcından bitimine kadar, seçimin düzen içinde yönetimi ve güvenliği ile ilgili bütün işlemleri yapma ve yaptırma; seçim süresince ve seçimden sonra seçim konularıla ilgili bütün yolsuzlukları, şikayet ve itirazları inceleme ve kesin karara bağlama ve Türkiye Büyük Millet Meclisi üyelerinin seçim tutanaklarını ve Cumhurbaşkanlığı seçim tutanaklarını kabul etme görevi Yüksek Seçim Kurulunundur. $\mathrm{Bu}$ nedenle, 7062 sayılı Kanun'un gerekçesinde de ifadesini bulan, Kurul'un iş yükünün arttığı ve ayrıntılı bir teşkilat kanununa ihtiyaç duyulduğu tespitine katılmak gerekir. Dolayısıyla, Kurul'un teşkilatına, oluşumuna, görev, yetki ve çalışma usulüne ilişkin seçim mevzuatında dağınık halde bulunan kuralların derlenmesi ve gerekli değişikliklerin yapılması adına ayrı bir kanunun kaleme alınması yerinde olmuştur. Buna karşın, söz konusu hedefleri gerçekleştirmek amacıyla hazırlanan bir kanun metninde bugüne kadar seçim hukukunda yaşanan uyuşmazlıklarda tartışma konusu olmuş pek çok konunun ele alınmadığı ve seçim mevzuatında var olan bir takım çelişkilerin ve tutarsızlıkların giderilmediği görülmektedir. Oysaki Yüksek Seçim Kurulu'nun yapısını ve işleyişini sistematik bir biçimde düzenlemeyi amaçlayan bir kanun metninde, var olan sorunların çözülmesi ve eksikliklerin giderilmesi yerinde olabilirdi. Güçlü bir teşkilat kurma iddiasıyla hazırlanan 7062 sayılı Kanun'un ise bu beklentileri tam olarak karşılayamadığı ifade edilmelidir. Kanun, bu açıdan eleştiriye açıktır.

Bitirirken eklemek gerekir ki, Kanun teklifinin ilk halinde yer alan ve seçim sürecinin ayrılmaz bir parçası olan siyasi partilerin bu sürece katılmalarını büyük ölçüde zorlaştıran bir takım düzenlemeler, Anayasa Alt Komisyonu'nda teklif metninden çıkarılmıştır ${ }^{29}$. Teklif metni üzerinde

${ }^{29}$ Teklifin özgün halinde yer alan ve Anayasa Alt Komisyonu'nda metinden çıkarılan düzenlemelerin ilki, sandık başkanlarını belirleme yöntemine ilişkindi. Teklifin, 298 sayılı Kanun'un 22. maddesini değiştiren 12/4 maddesine göre, ilçe seçim kurulu başkanı, ilçede görev yapan ve sandık kurulu başkanlığına mani hali bulunmayan kamu görevlilerinin listesini yapacak ve bu listeden sandık kurulu başkanlarını belirleyecekti. Böylece, siyasi partiler, sandık başkanını belirleme sürecinde etkisiz hale gelmiş olacaktı. İkinci olarak, teklifin, 298 sayılı Kanun'un 25. maddesini değiştiren 12/6 maddesiyle, siyasi partiler ve bağımsız adaylar tarafından müşahit görevlendirilebilmesi süreci ciddi ölçüde zorlaştırılmaktaydı. Buna göre; ilçede bulunan sandık sayısının iki katına kadar müşahit adına düzenlenmiş fotoğraflı müşahit kartı ilçe seçim kurulu başkanlığına teslim edilmeli; müşahit kartları ilçe seçim kurulu başkanlığınca kontrol edilerek mühürlenmeli ve oy verme gününden önce ilgili siyasi parti temsilcisi veya bağımsız adaya teslim edilmeliydi. Aynı maddeye göre, müşahit kartı yanında 
yapılan bu değişikliklerin serbest, adil, şeffaf ve güvenilir bir seçim süreci adına yerinde olduğu belirtmek gerekir. Ayrıca, söz konusu değişikliklerin, Komisyon görüşmelerinde iktidar ve muhalefet partilerinin uzlaşması sonucunda gerçekleştirilmiş olması da seçim hukuku alanında yapılan bu gibi düzenlemelerin yapım süreçleri adına olumlu bir örnek olarak değerlendirilebilecektir. Buna karşın, 13.03.2018 tarihli ve 7102 sayılı Seçimlerin Temel Hükümleri ve Seçmen Kütükleri Hakkında Kanun ile Bazı Kanunlarda Değişiklik Yapılmasına Dair Kanun'un, bu yorumları kısmen geçersiz kıldığı da ifade edilmelidir. Öyle ki, 7062 sayılı Kanun'a ilişkin teklifin özgün halinde yer alan; ancak, Anayasa Alt Komisyonu'nda metinden çıkarılan ve siyasi partileri seçim sürecinde etkisiz hale getireceği gerekçesiyle eleştirilere konu olan "sandık kurulu başkanlarını belirleme" sürecine ilişkin düzenleme, 7102 sayılı Kanun ile hukuk hayatına girmiş bulunmaktadır ${ }^{30}$.

\section{KAYNAKÇA}

\section{Kitaplar ve Makaleler}

COŞKUN, Sabri: Seçim Hukuku, Mahalli İdareler Derneği Yayınları, Ankara 2007.

DEMIROĞLU, Kemal / KARAGiL, Nevzat: Yeni Seçim Kanunlarının Mufassal Şerhi ve Tatbikat1, Siralar Matbaası, İstanbul 1961.

ERDEM, Tarhan: Anayasalar ve Seçim Kanunları: 1876-1982, Milliyet Yayınları, İstanbul 1982.

GÖNENÇ, Levent: Türkiye'de Seçim Uyuşmazlıkları ve Çözüm Yolları, Adalet Yayınevi, Ankara 2008.

bulunmayan veya istenildiğinde ibraz etmeyen kişiler sandık başı işlemlerini takip edemeyeceklerdi. Buna ek olarak, müşahit kartının şekil ve içeriği ile teslim edilme süresi Yüksek Seçim Kurulunca belirlenecek ve süresi içinde söz konusu kartlan teslim etmeyen siyasi partiler ve bağımsız adaylar, sandık başında müşahit bulunduramayacaklardı. Bkz. Türkiye Büyük Millet Meclisi Anayasa Komisyonu Raporu, Esas No. 2/1929, Karar No. 7, 28.11.2017, s. 24-67.

${ }^{30}$ Bkz. 7102 sayll Kanun Madde 3:

"298 sayılı Kanunun 22 nci maddesi başlığıyla birlikte aşağıdaki şekilde değiştirilmiştir:

Sandık kurulu başkanının belirlenmesi

MADDE 22- İlçede görev yapan tüm kamu görevlilerinin listesi, mülki idare amiri tarafindan yerleşim yeri adresleri esas alınmak suretiyle ilgili ilçe seçim kurulu başkanlıklarına gönderilir. İlçe seçim kurulu başkanı, bu kamu görevlileri arasından ihtiyaç duyulan sandık kurulu başkanı sayısının iki katı kamu görevlisini ad çekme suretiyle tespit eder ve bu kişiler arasından mani hali bulunmayanları sandık kurulu başkanı olarak belirler.

Sandık kurulu başkanının göreve gelmemesi halinde, kamu görevlileri arasından belirlenen üye, bu üyenin de bulunmaması durumunda en yaşlı üye kurula başkanlık eder.” 
GÖNENÇ, Levent: "Yüksek Seçim Kurulu Yasası Üzerine Bir Değerlendirme”, Türkiye Ekonomi Politikaları Araştırma Vakfı, Aralık 2017.

HATIPOĞLU, Muzaffer / PARLAR, Ali: Açıklamalı-Gerekçeli-İçtihatlı Seçim Kanunları ve Seçim Suçları, Ankara 2004.

OWEN, David: "Democracy", Political Concepts içinde, Bellamy, Richard / Mason, Andrew (ed.), Manchester University Press, Manchester 2003.

PRZEWORSKI, Adam: "Minimalist Conception of Democracy: A Defense", Democracy's Value içinde, SHAPIRO, Ian / HACKER-CORDON, Casiano (ed.), Cambridge University Press, Cambridge 1999.

TÜRK HUKUK KURUMU: Türk Hukuk Lûgatı, Başbakanlık Mevzuatı Geliştirme ve Yayın Genel Müdürlüğü, 3. b., Ankara 1991.

\section{Diğer Kaynaklar}

OFFICE FOR DEMOCRATIC INSTITUTIONS AND HUMAN RIGHTS (OSCE):

"Resolving Election Disputes in the OSCE Area: Towards a Standard Election Dispute Monitoring System", 2000, https://www.osce.org/odihr/elections/17567?download=true, (Erişim Tarihi: 20.03.2018).

Resmi Gazete, Çeşitli Sayılar.

Türkiye Büyük Millet Meclisi Anayasa Komisyonu Raporu, Esas No. 2/1929, Karar No. 7, 28.11.2017.

Yüksek Seçim Kurulu, Çeşitli Kararlar.

Yüksek Seçim Kurulu'nun Teşkilat ve Görevleri Hakkında Kanun Teklifi, TBMM Başkanlığı, Esas No. 2/1929, 21 Kasım 2017. 
